\title{
Dorongan Psikis Tokoh pada Novel Ayat-Ayat Cinta 2 Karya Habiburrahman El Shirazy (The Psikis Drive of the Characters of Ayat-Ayat Cinta 2 Novel By Habiburrahman El Shirazy)
}

\author{
Abdul Rozak ${ }^{\mathrm{a}, 1}$, Atikah Atikah ${ }^{\mathrm{a}, 2}$, dan Diana Rahmawati Rozak ${ }^{\mathrm{a}, 3}$ \\ ${ }^{a}$ Universitas Swadaya Gunung Jati, Cirebon, Indonesia \\ 1'abdurrozak58@gmail.com; ${ }^{2}$ atikahkartika4@gmail.com; dianarozak26@gmail.com
}

Article info ABSTRACT

Article history:

Received: 24-02-2021

Revised : 18-05-2021

Accepted: 10-06-2021

Keywords:

Ayat-Ayat Cinta 2

character in novel

psychic encouragement

The purpose of this study was to describe the concept of psychic impulses in the characters in the novel Ayat-Ayat Cinta 2 by Habiburrahman El Shirazy. This study uses a qualitative method with a descriptive-analytical working mechanism. The approach used is a literary psychology approach. The data collection technique applied is documentation. The data analysis activities consist of data reduction, data presentation, and concluding/verification. The results of the study indicate that there is an impetus that drives or underlies the behavior of each character. Interaction between characters leads to encouragement, namely encouragement that comes from the spiritual aspect, encouragement to fulfill desires without regard to values, and encouragement that is influenced by news in the mass media. Changes in the character of the antagonist are influenced by the behavior of practicing the Qur'an and hadith by the main character. Thus, reflected in the pattern of the relationship between individual history, goals, and aspirations of individuals to the behavior of the characters.

Tujuan penelitian ini adalah untuk mendeskripsikan konsep dorongan psikis pada tokoh dalam novel Ayat-Ayat Cinta 2 karya Habiburrahman El Shirazy. Penelitian ini menggunakan metode kualitatif dengan mekanisme kerja deskriptif analitik. Pendekatan yang digunakan adalah pendekatan psikologi sastra. Teknik pengumpulan data yang diaplikasikan adalah dokumentasi. Aktivitas analisis data tersebut terdiri atas reduksi data, penyajian data, dan penarikan kesimpulan/verifikasi. Hasil penelitian menunjukkan bahwa terdapat dorongan yang menggerakkan atau melatarbelakangi perilaku setiap tokoh. Interaksi antartokoh mengarah pada adanya dorongan, yakni dorongan yang berasal dari aspek spiritualitas, dorongan memenuhi keinginan tanpa memperhatikan nilai-nilai, dan dorongan yang dipengaruhi oleh pemberitaan di media massa. Perubahan karakter tokoh antagonis dipengaruhi perilaku pengamalan Al-Qur'an dan hadis oleh tokoh utama. Dengan demikian, tercermin adanya pola hubungan antara sejarah individu, tujuan, dan aspirasi individu terhadap perilaku tokoh.

Copyright @ 2021 Institut Agama Islam Negeri Syekh Nurjati Cirebon. All rights reserved

\section{PENDAHULUAN}

Manusia dan segala bentuk perilakunya memiliki pola gambaran yang dapat dicermati melalui ragam ilmu, seperti psikologi. Imron (2015) menunjukkan 
adanya dorongan atau kekuatan yang menggerakkan aktivitas pada makhluk hidup, membentuk pola tingkah laku, dan mengarahkan pada tujuan tertentu. Dorongan tersebut terbagi atas dorongan fisiologis, psikologis, dan dorongan spiritual. Hal demikian berelasi dengan karya sastra sebagai karya imajiner, menyajikan unsur lakon dan karakternya melalui alur tertentu yang juga dapat diamati melalui konsep psikologi sastra. Tingkah laku manusia selalu berkaitan dengan konsep dorongan. Konsep dorongan tersebut sering juga dipahami sebagai motivasi. Dalam kacamata teori psikologi, dorongan merupakan kunci dalam memahami banyak literatur (McMahan, 2017). Dorongan sebagai kekuatan yang terdapat di dalam diri manusia dan memiliki tujuan tertentu berlangsung di luar kesadaran manusia (Emzir \& Syaiful, 2016).

Dorongan sebagai energi yang menggerakkan badan merupakan stimulus yang berasal dari dalam yang menggerakkan badan (Prawira, 2012). Dorongan juga diartikan sebagai suatu kondisi internal otot-otot yang melepaskan energi dan menghasilkan atau menyebabkan aktivitas-aktivitas. Dorongan merupakan aktivitas umum. Dorongan bermakna aktivitas khusus yang terarah pada suatu tujuan. Menurutnya, dalam psikologi manusia, dorongan adalah fokus motivasi dalam kepribadian, maksud, dan interes. Psikisme manusia terbagi atas id, ego, dan super ego (Minderop \& Stanton, 2011). Konsep tersebut berhubungan dengan tingkah laku manusia. Dorongan dianggap sebagai energi fisik yang mengaktivasi organisme melakukan suatu tindakan (Prawira, 2012). Berdasar pada pendapat tersebut, penulis melakukan penelaahan teks sastra berupa aspek-aspek yang menunjukkan adanya dorongan sehingga terjadinya suatu tindakan.

Energi fisik merupakan manifestasi energi kehidupan dan energi organisme sebagai suatu sistem biologis (Wilcox, 2013). Tingkah laku manusia dipengaruhi oleh kepribadian, tujuan, dan aspiras (Mulyaningsih, 2015). Manusia dibentuk dan dipolakan oleh akumulasi pengalaman generasi masa lalu yang jauh ke belakang. Hal tersebut menunjukkan peran energi fisik atau dorongan dalam melakukan suatu tindakan, terkait dengan tingkah laku manusia. Karya sastra tidak terlepas dari kondisi psikologis pengarang dan penggambaran psikologi tokoh di dalamnya. Psikologi sendiri merupakan ilmu yang bersangkutan dengan kehidupan dan perilaku mental manusia. Psikologi lebih dari sekadar studi tentang perilaku, psikologi adalah studi mengenai mental dalam kehidupan. Mentalitas itu sendiri berkorelasi dengan perilaku. Meskipun, dalam mempelajari mental tidak hanya dapat dilakukan melalui perilaku, tetapi dapat pula dari pengalaman dan bukti lain (Borchardt, 1984). Motivasi merupakan kekuatan yang mendorong manusia dalam melakukan tindakan, baik dorongan yang berasal dari kekuatan positif maupun negatif (Schiffman \& Kanuk, 2010).

Sastra merupakan catatan kesadaran manusia yang paling kaya dan paling komprehensif (Lodge, 2002). Salah satu karya sastra yang banyak mencerminkan kehidupan umat manusia adalah novel. Novel sebagai karya fiksi yang berisi imajinasi dan pengetahuan, bergabung untuk mengekspresikan kehidupan dalam bentuk cerita dan imajinasi. Novel selalu diarahkan dan dikendalikan oleh pengetahuan (Long, 2004). Di dalam novel, memuat unsur tokoh yang berelasi dengan manusia dan menganggap dirinya sebagai manusia adanya (Warsiman, 2016). Adapun penokohan adalah teknik pengarang menggambarkan dan mengembangkan watak tokoh dalam sebuah karya fiksi (Esten, 2013). Minat seseorang pada sastra bukan karena adanya pengenalan terhadap diri, tetapi karena dalam sastra seseorang mengetahui hal yang tidak diketahui tentang diri sendiri 
(Milner, 1980). Sastra menyajikan kebenaran, kebenaran yang tak diakui, kebenaran yang direpresi, dan kebenaran tersebut merupakan wilayah kekuatan sastra. Dalam memandang manusia, Yusuf \& Nurihsan (2011) menggabungkan pandangan teleologi dan kausalitas. Jung memandang tingkah laku manusia ditentukan tidak hanya oleh sejarah individu dan rasi atau kausalitas, tetapi juga oleh tujuan dan aspirasi individu. Masa lampau individu sebagai aktualitas maupun masa depan individu sebagai potensialitas sama-sama membimbing tingkah laku individu.

Pendekatan yang dimanfaatkan dalam penelitian ini, adalah psikologi sastra. Psikologi sastra menekankan pada telaah aspek sastra yang mencerminkan proses dan aktivitas kejiwaan. Pendapat tersebut menunjukkan bahwa karya sastra sebagai sebuah cermin, yakni cermin proses dan kejiwaan manusia (Minderop \& Stanton, 2011). Aktivititas kejiwaan tokoh dalam sebuah karya sastra dapat tergambar salah satunya melalui perilaku tokoh. Hal tersebut sebagai salah satu cara yang dapat digunakan untuk mengetahui konsep motivasi atau dorongan psikis tokoh. Psikologi sastra sebagai salah satu aliran sastra yang berusaha mengeksplorasi pikiran tokoh utama, terutama pada bagiannya yang terdalam, yaitu alam bawah sadar (Wilcox, 1995). Stanton (2012) membatasi psikologi sastra sebagai aliran yang berusaha menemukan pola pikiran tokoh utama yang juga terkait dengan bagian alam bawah sadar.

Terdapat penelitian relevan yang telah dilakukan oleh para peneliti sebelumnya. Gammelgaard (2011) dalam penelitiannya menemukan sumbangsih Lacan berupa konsep keinginan, yang harus dibedakan dari dorongan dan cinta. Perbedaan antara hasrat, dorongan, dan cinta memperkenalkan perspektif yang diperlukan untuk pembacaan psikoanalitik atas karya Proust. Tujuan utamanya adalah membaca tokoh protagonis, Albertine dan Baron de Charlus, masingmasing sebagai wakil dari perubahan cinta dan dorongan. Aras (2014) menyatakan bahwa pekerjaan sastra dan seni memungkinkan individu untuk menyadari kepribadian mereka, perbedaan individu, untuk mempertanyakan kehidupan dan keberadaan, serta data utama di bidang psikologi. Penelitan Pangestu \& Sunardi (2016) menemukan muatan mekanisme pertahanan diri pada karakter utamanya dan bukti inti. Penyebab potensial mekanisme pertahanan diri juga dapat disimpulkan dari karakter perkembangan dan masa kecil.

Penelitian Bahador \& Zohdi (2015) menemukan adanya ketidaksadaran akan karakter wanita tercermin dalam mimpinya sebagai akibat dari represi dan dorongan serta keinginan sosial. Penelitian Hun \& Ummi (2018) menunjukkan bahwa Ayat-ayat Cinta 2 memanfaatkan konsep cinta romantis dengan penekanan pada keintiman seksual. Sementara itu, Salju Sakinah lebih menekankan pada bahasa pemahaman keintiman fisik. Penelitian Rani (2014) menemukan konsep hubungan konflik cinta sebagai tema utama dalam dua novel, yakni novel Salju Sakinah oleh Zaid Akhtar dan Hidayah Cinta oleh Ilham Hamdani. Penelitian terhadap novel Ayat-Ayat Cinta 2 juga telah dilakukan oleh para peneliti lain. Penelitian Atin (2018) terfokus pada nilai-nilai aqidah dengan hasil ditemukannya nilai aqidah dalam rukun iman. Penelitian Mukti, dkk. (2017) menemukan adaya masalah sosial berupa kemiskinan, kejahatan, disorganisasi, peperangan, pelanggaran terhadap norma, masalah kependudukan, dan masalah birokrasi. Penelitian Rozak, dkk. (2019) mengungkapkan adaya fakta kemanusiaan dalam novel Ayat-Ayat Cinta 2 yang berkaitan dengan wujud fisik dan mental, fakta 
sosial, berkaitan dengan ilmu pengetahuan, kaidah institusi sosial, fakta sejarah, serta peristiwa yang berdampak pada kehidupan.

Penelitian-penelitian psikologi sastra tersebut memiliki perbedaan dengan penelitian yang dilakukan oleh penulis, yakni berupa tujuan dan objek penelitian. Penelitian mengenai konsep dorongan psikis dalam karya sastra ini menekankan pada kekuatan yang dimiliki tokoh dalam melakukan suatu tindakan. Habiburrahman El Shirazy berhasil mengemas Novel Ayat-Ayat Cinta 2 sebagai sebuah novel yang menampilkan bentuk emosi, yakni cinta dan benci sekaligus yang didasari oleh pengalaman dan proses belajar. Berhubungan dengan keyakinan, psikologi islam menyatakan bahwa konsep motivasi dipengaruhi oleh fitrah ruhaniah. Manusia yang berdasar pada fitrah ruhaniah berelasi dengan adanya sikap menerima nilai kebenaran melalui perilaku luhur, manusiawi, damai yang ditempuh dengan jalan takziyah an-Nafs (Rois, 2019). Novel Ayat-Ayat Cinta 2 memuat gambaran fakta kemanusiaan tentang islamofobia, tentang konflik Palestina Israel, tentang pendidikan, sosial, dan kisah cinta Fahri dengan istrinya. Pengarang mendeskripsikan Fahri sebagai tokoh yang perpengetahuan dan memiliki keyakinan yang kuat akan ajaran Islam. Berdasarkan gambaran tersebut, maka penelitian ini terfokus pada analisis dorongan psikis tokoh dalam melakukan suatu tindakan.

\section{METODE}

Penelitian dorongan psikis pada karakter tokoh di dalam sebuah karya sastra ini dilakukan pada Agustus tahun 2020. Metode penelitian yang digunakan untuk menganalisis Novel Ayat-Ayat Cinta 2 adalah metode deskriptif kualitatif. Penelitian kualitatif merupakan studi yang menghasilkan data deskriptif berbentuk kata-kata tulis atau lisan dari perilaku yang dapat diamati (Sugiyono, 2014). Sumber data utama penelitian ini adalah Novel Ayat-Ayat Cinta 2 karya Habiburrahman El Shirazy. Penelitian ini didukung dengan adanya sumber data lain yang berupa buku teori dan jurnal-jurnal yang relevan. Adapun data dalam penelitian ini adalah kata, frasa, kluasa, kalimat, dan paragraf yang menggambarkan dorongan psikis dalam novel Ayat-Ayat Cinta 2 karya Habiburrahman El Shirazy.

Teknik pengumpulan data yang digunakan adalah teknik studi dokumen atau pustaka. Studi dokumentasi diaplikasikan dengan cara mencatat data yang terdapat di dalam dokumen, yakni novel Ayat-Ayat Cinta 2 karya Habiburrahman El Shirazy. Dalam menganalisis data, penulis memanfaatkan model Milles dan Hubberman. Aktivitas analisis data dilakukan secara interaktif dan berlangsung secara terus-menerus sampai tuntas atau sampai data sudah jenuh. Adapun kegiatannya berupa pengumpulan data, reduksi data, penyajian data, dan penarikan simpulan (Milles, Matthew B. \& Hubberman, 2014). Teknik validitas data yang digunakan adalah teknik triangulasi teori. Untuk menemukan deskripsi dorongan psikis diperlukan berbagai teori psikologi, seperti teori tingkah laku dan dorongan serta teori psikologi sastra yang disampaikan oleh Minderop \& Stanton (2011). 


\section{HASIL DAN PEMBAHASAN}

Berikut ini analisis berdasarkan data yang terkumpul.

\section{Dorongan Psikis Tokoh Fahri Abdullah}

Novel Ayat-Ayat Cinta 2 menyajikan permasalahan yang berhubungan dengan keyakinan. Fahri Abdullah mengalami berbagai permasalahan dengan tokoh Keira, Jason, dan lainnya karena Fahri adalah seorang muslim. Namun demikian, tindakan atau perilaku Fahri mencerminkan keselarasan dengan ajaran agamanya. Hal demikian tergambar melalui data berikut.

"Aku berlindung kepada Allah dari ketergantungan kepada materi dan uang. Allahush shamad. Hanya Allah tempat bergantung. Paman, apakah Paman tidak kenal aku? Kata-kata Paman sungguh, aku jadilah introspeksi. Tapi Paman, ketahuilah, teladanku dalam menyelesaikan persoalan hidup adalah Baginda Nabi dan para sahabat. Ketika menolong Keira, Sabina dan Nenek Catarina harus mengeluarkan uang. Memang itu diperlukan sebagai wasilah. Apakah Paman lupa, Abu Bakar memakai uang untuk memerdekakan Bilal bin Rabbah dari perbudakan? Rasulullah membayar harga unta Abu Bakar ketika hijrah!” (Shirzy, 2016: 487).

Fahri memasrahkan diri atas tindakannya membantu Keira, Sabina, dan Nenek Catarina dengan memberikan uang. Fahri merasa takut tindakannya merupakan perbuatan salah. Oleh karena itu, ia meminta perlindungan kepada Allah Subhanahu wa ta'ala dari ketergantungan pada materi dan uang. Tindakan demikian mencerminkan keyakinannya pada Alquran dan hadis. Tergambar struktur kepribadian tokoh Fahri yang tidak terlepas dari keyakinannya pada Alquran dan hadis. Kepribadiannya diterangkan melalui tindakan-tindakan Fahri dalam menolong tetangganya. Dengan demikian, dorongan yang menggerakkan Fahri dalam membantu tokoh lainnya dipengaruhi oleh pengetahuan dan keyakinannya pada ajaran agamanya. Bentuk dorongan yang berupa aspek spiritualitas juga tergambar pada data berikut.

"Kita beramal tidak usah pakai tapi-tapian Paman. Kita berusaha ikhlas, namun demikian hanya Allah saja yang berhak menilai. Jika itu semua diterima Allah sebagai amal shaleh selain mengharap ridha-Nya di akhirat, aku berharap pahalanya sampai kepada Aisha, jika Aisha benar-benar telah mati. Jika masih hidup, aku berharap itu membuat Aisha selalu dirahmati oleh Allah dan dalam kondisi apapun juga aku masih diberi kesempatan oleh Allah berjumpa dengannya Paman." (Shirzy, 2016: 226)

Fahri digambarkan sangat merasa sedih saat istrinya hilang di tanah Palestina. Ia terus berusaha melakukan perbuatan yang dapat memberikan manfaat untuk sesama. Tindakan Fahri tersebut merupakan cerminan kejiwaan tokoh berupa super ego. Kesedihan yang dialami oleh Fahri direspons dengan tindakan melakukan amal-amal saleh. Tercermin adanya pengamalan nilai-nilai yang terdapat di dalam Alquran dan hadis. Ia meminta Paman Hulusi untuk dapat melakukan perbuatan baik dengan berusaha menjaga keikhlasannya. Rasa cintanya pada Aisha ditunjukkan dengan harapan dan doanya, yakni setiap amal yang dilakukan dapat sampai kepada istrinya tersebut. Dorongan yang 
menggerakkan Fahri tidak terlepas dari aspek spiritualitasnya. Hal demikian juga tergambar pada data di bawah ini.

"Maaf, kami tidak bisa minum segala wine. Kami muslim. Kami tidak minum segala minuman yang mengandung alkohol. Mohon maaf. Kami tidak bermaksud menolak...." (Shirazy, 2015: 165)

Penggalan tersebut mengandung perilaku atau sikap Fahri Abdullah yang berkaitan dengan tokoh Brenda. Brenda yang merupakan nonmuslim berniat memberikan hadiah kepada Fahri karena kebaikan Fahri. Akan tetapi, Fahri menolak pemberian hadiah tersebut karena hadiahnya adalah minuman beralkohol. Fahri menolak pemberian Brenda tersebut karena keyakinannya atas larangan meminum minuman yang dapat memabukkan. Brenda merupakan salah satu tetangga Fahri yang sejak awal memiliki sikap baik pada Fahri dan Paman Hulusi sebagai muslim. Sementara itu, beberapa tokoh lainnya bersikap kurang baik. Terdapat cerminan tindakan Fahri dalam berhati-hati untuk menolak minuman beralkohol yang dihadiahkan Brenda. Dalam kutipan tersebut, tindakan Fahri didorong oleh pengetahuan dan keyakinannya akan larangan meminum alkohol menurut Alquran dan hadis.

\section{Dorongan Psikis pada Tokoh Keira terhadap Fahri}

Selain berkaitan dengan keyakinan yang kuat akan ajaran Islam, terdapat gambaran sikap yang didorong atas pengalaman atau pengetahuannya dari berita yang ditonton atau dibaca. Data berikut ini memuat dorongan psikis tokoh Keira.

“... sejak itu saya benci muslim, karena pengebom itu katanya muslim. Jason, adik saya ini, saya doktrin untuk membenci muslim....” Ucap Keira. (Shirazy, 2015: 623)

Kutipan di atas menunjukkan konflik batin tokoh Keira berupa kebenciannya terhadap muslim. Dari kalimat di atas, diketahui bahwa Keira membenci muslim karena pengeboman yang menewaskan ayahnya dilakukan oleh muslim. Hal tersebut diketahui Keira melalui berbagai pemberitaan di media massa. Kondisi Keira yang membenci muslim pun tergambarkan melalui sikapnya, yakni mendoktrin Jason untuk membenci muslim. Dorongan kebencian yang dimilikinya menjadikan ia bersikap tidak baik atau menunjukkan bahwa dia memusuhi Fahri dan Paman Hulusi sebagai seorang muslim. Beberapa kali Keira menunjukkan kebenciannya dengan menulisi mobil Fahri dengan kalimat-kalimat kebencian, menuduh Fahri, dan lainnya. Kutipan berikut ini juga menggambarkan dorongan psikis tokoh Keira.

Keira melelang ke-virginan-nya. Keira membuka angka seratus ribu poundsterling. (Shirazy, 2015: 211)

Data di atas menggambarkan konflik tokoh Keira yang berhubungan dengan pergulatan batinnya tanpa disebabkan atau dipengaruhi orang lain di sekitarnya. Tokoh Keira hendak melelang kevirginannya karena keinginannya untuk dapat sekolah di tempat yang banyak melahirkan pemain biola yang besar dan terkenal. Pada permasalahan tersebut, Keira tidak lagi memegang nilai-nilai kebenaran, ia menekan nilai-nilai kebenaran dan melakukan perbuatan yang bertentangan 
dengan nilai-nilai kebenaran. Tergambar adanya keinginan yang kuat untuk mencapai cita-citanya menjadi pemain biola terkenal. Keinginan tersebut mendorongnya melakukan perbuatan yang bertentangan dengan nilai-nilai kebenaran.

Nukilan di bawah ini menggambarkan interaksi antara Keira dan Fahri. Sikap Keira terhadap Fahri mempengaruhi Fahri untuk membuktikan bahwa Islam tidak seperti yang disangka Keira. Berikut adalah kutipannya.

"Sungguh, Keira, saya tidak ingin hal ini sampai engkau ketahui. Saya hanya ingin melihat kamu bahagia meraih cita-citamu, mencetak prestasi dengan bakat luar biasamu." (Shirazy, 2015: 636-637).

Penggalan di atas memuat konflik batin tokoh utama, Fahri Abdullah yang selama ini mendapatkan perlakuan buruk dari tokoh Keira. Konflik tersebut tergambar melalui tindakan Fahri meminta maaf pada Keira karena telah membantu Keira mendanainya sekolah hingga mencapai mimpi-mimpinya. Fahri juga merahasiakan tindakannya tersebut agar Keira mau menerima bantuannya.

Super ego yang ditunjukkan pada penggalan di atas dipengaruhi oleh keyakinannya pada Alquran dan hadis. Fahri menunjukkan bahwa Islam mengajarkan manusia untuk tetap bersikap baik dan menunjukkan bahwa Islam bukan agama yang penuh kebencian, seperti yang diprasangkakan oleh tokoh Keira. Sikap yang dikendalikan oleh nilai baik dan buruk tersebut dapat disebut super ego. Dalam hal ini, tergambar bahwa tokoh utama bertindak dengan dasar dorongan psikis yang dipengaruhi oleh keyakinannya pada Alquran dan hadis.

\section{Dorongan Psikis Tokoh Jason terhadap Fahri}

Salah satu tokoh yang digambarkan membenci Fahri adalah Jason, adik Keira yang didoktrin untuk membenci Islam. Data berikut memuat gambaran dorongan psikis tokoh Jason dalam melakukan suatu tindakan.

Jason memasang muka tidak suka, bibirnya memberikan isyarat berbicara pada Fahri tanpa suara: fuck you.! (Shirazy, 2015: 33)

Nukilan novel tersebut memuat konflik tokoh Jason yang membenci muslim. Hal tersebut berdasar pada keyakinannya bahwa muslim adalah teroris. Kebencian tersebut tercermin melalui sikap dan perkataan penuh kebencian yang diucapkan tokoh Jason kepada Fahri. Pada tahap ini, terlihat Jason tidak menekankan pada aspek ego dan super ego. Sikap demikian didorong oleh doktrin Keira tentang muslim sebagai tokoh yang harus bertanggung jawab atas peristiwa pengeboman yang menewaskan ayah kandung Keira. Konsep dorongan pada tokoh Jason juga tergambar melalui kutipan berikut.

"Aku ingin pindah agama Islam." "Kau serius, Jason?" "Aku serius." (Shirazy, 2015: 462-463)

Pada nukilan di atas, terdapat deskripsi keinginan dan pergulatan batin pada tokoh Jason. Aspek super ego tergambar melalui keinginan Jason untuk berpindah agama Islam. Hal tersebut karena Jason telah mempertimbangkan nilai baik dan buruk. Jason melihat muslim bernama Fahri sangat berbanding terbalik dengan hal yang diberitakan di media massa. Pada tahap ini, Jason lebih menekankan aspek kepribadian berupa super ego. Tindakan atau sikap Jason yang mengalami 
perubahan tidak terlepas dari tokoh Fahri yang selalu berusaha mengamalkan ilmunya atau keyakinannya pada Alquran dan hadis.

\section{Dorongan Psikis Tokoh Sabina atau Aisha}

Selain Fahri, terdapat tokoh Sabina atau Aisha yang sebenarnya adalah istri Fahri. Tokoh Sabina juga mencerminkan sikap yang bersesuaian dengan ajaran agamanya. Hal demikian tergambar melalui kutipan berikut.

"Kau yang anak pelacur! Anak kera! Dengar, aku siap mempertaruhkan nyawaku demi membela kehormatam nabiku dan keluarganya." (Shirazy, 2015: 502)

Nukilan novel di atas mengandung konflik yang disebabkan oleh tindakan tokoh Baruch yang menghina Rasulullah dan keluarganya. Sabina digambarkan melakukan perlawanan pada tokoh Baruch karena adanya aspek super ego. Ia bertindak atau melakukan respons atas dasar keyakinannya pada agama Islam, yakni Alquran dan hadis. Oleh karena itu, keberanian tokoh Sabina didorong oleh ajaran agamanya. Sikap demikian juga tergambar melalui kutipan berikut.

"...Lebih baik wajahku rusak tapi kehormatanku tidak rusak. Itu yang ada di dalam pikiranku saat itu.” (Shirazy, 2015: 686)

Kutipan di atas memuat penggambaran masalah internal dan eksternal. Konflik batin tergambar melalui tindakan Sabina yang merusak wajahnya agar ia terhindar dari tindakan tokoh Baruch yang hendak merusak kehormatannya. Hal tersebut menggambarkan struktur kepribadian berupa super ego. Dorongan yang mendasari perbuatan tokoh Sabina tersebut berhubungan dengan aspek spiritualitas. Ia berusaha menjauhi perbuatan tercela yang dilakukan oleh Baruch, yakni pemerkosaan. Keberanian Sabina merusak wajahnya tersebut dilakukan untuk tetap menjaga kehormatannya. Tergambar pula kecintaan Sabina pada Fahri, suaminya melalui sikap menjaga kehormatan dirinya.

Dorongan Psikis Tokoh Nenek Catarina, Baruch, dan Madam Varenka terhadap Fahri

Terdapat berbagai permasalahan yang ditunjukkan melalui sikap, baik sikap positif maupun negatif pada tokoh Yahudi, seperti Nenek Catarina, Baruch, dan Madam Varenka. Hal demikian tergambar melalui kutipan berikut.

Saya pernah membaca pembahasan masalah ini. Menurut ajaran mereka, di dalam Kitab Ester dalam Tanakh, Haman seorang wazir jahat musuh Yahudi digambarkan sebagai bangsa keturunan amalek. Yaitu sebuah bangsa yang digambarkan sangat membenci dan sangat ingin menghancurkan Bani Israel setelah mereka eksodus dari Mesir. Lha, di dalam Taurat mereka, Tuhan memberi perintah kepada mereka agar memusnahkan semua orang amalek sepanjang sejarah, sampai tidak ada orang amalek yang hidup. Celakanya, pada abad modern ini, beberapa kalangan Yahudi ekstrem manganggap bangsa Palestina, Arab dan bahkan muslim itu sebagai amalek. Atau sama dengan amalek. Atau wujud amalek modern." (Shirazy, 2015: 108)

Cuplikan novel di atas memuat gambaran aspek dorongan yang melatarbelakangi adanya suatu tindakan atau sikap yang dilakukan oleh Nenek Catarina dan Fahri. Data di atas lebih banyak menggambarkan konflik Fahri dengan tokoh-tokoh Yahudi ekstrem. Sebagai seorang Yahudi, Nenek Catarina 
bukanlah seorang yang membenci muslim dan memandang muslim sebagai sesuatu yang disebut amalek. Meskipun, pada awalnya Nenek Catarina memandang Fahri sebagai amalek, tetapi Nenek Catarina menerima kebaikan Fahri dan membalas kebaikannya dengan kebaikan.

Penggalan-penggalan di atas menggambarkan konflik yang terjadi sebagai akibat dari perbedaan keyakinan. Adanya konsep amalek yang dijelaskan sebagai bangsa yang membenci dan menginginkan kehancuran Bani Israel. Hal tersebut dikatakan oleh Fahri dengan bersumber pada Kitab Ester dalam Tanakh. Fahri mengatakan bahwa beberapa Yahudi ekstrem menganggap Palesina, Arab, dan muslim sebagai amalek. Hal tersebut merupakan pengetahuan yang didapatkan dengan melalui proses belajar dan menjadi dorongan untuk Fahri dapat bersikap dalam menghadapi bangsa Yahudi, termasuk pada Nenek Catarina.

Fahri menjelaskan bahwa Goldstein merupakan Yahudi ortodoks yang ekstrem dengan keyakinannya bahwa amalek harus dibasmi. Goldstein dipengaruhi oleh ajaran-ajaran rasis Meir Kahane. Pembantaian di Masjid Hebron pada 25 Februari 1994 menewaskan 29 orang Palestina dan membuat 125 orang terluka. Data tersebut merupakan dasar pengetahuan Fahri dalam menyikapi tokoh-tokoh Yahudi. Fahri pun bersikap untuk tidak mendukung terjadinya peperangan yang mengatasnamakan agama. Fahri memandang perang agama tidak memberikan kontribusi apapun pada kehidupan manusia, selain kerugian. Ia memandang masalah Palestina dan Israel merpakan masalah teologi dan ideologi. Permasalahan tersebut harus dihadapi dengan kejujuran akan latarbelakang permasalahan yang sebenarnya.

Adapun dorongan berupa keyakinan dan pengetahuan akan sejarah tersebut mempengaruhi sikap Fahri dalam menghadapi tokoh Yahudi dan dalam merespons permasalahan Palestina. Fahri melakukan kegiatan penggalangan dana untuk anak-anak Palestina dengan melakukan pertunjukkan biola di Royal Miles. Hal tersebut merupakan salah satu tindakan yang didorong oleh pengetahuannya akan konflik Palestina dan Israel. Selain itu pada pembahasan konflik Nenek Catarina, Fahri digambarkan menyayangi Nenek Catarina dengan perbuatan menolongnya. Sikap tersebut juga dipengaruhi oleh pengetahuannya bahwa tidak semua Yahudi bersifat ekstrem. Dengan demikian, terdapat gambaran dorongan pengetahuan tokoh utama dalam menghadapi suatu persoalan.

Nenek Catarina yang sejak awal memandang Fahri sebagai amalek pun mengalami perubahan sikap. Fahri membantu Nenek Catarina ketika sakit, memberikan makanan, mengantarkan Nenek Catarina ibadah ke Sinagog, dan membantu dalam konflik dengan Baruch. Kebaikan Fahri tersebut menjadi dorongan untuk Nenek Catarina bersikap baik terhadap Fahri dan tetanggatetangga lainnya, seperti Paman Hulusi, Sabina, Brenda, dan lainnya.

Tokoh Baruch tidak hanya bersikap buruk pada Sabina, Fahri, tetapi juga pada Nenek Catarina, ibu tirinya. Sikap demikian didasari oleh dorongan tertentu. Berikut adalah kutipannya.

Di beranda rumah Nenek Catarina, tampak seorang lelaki menyeret Nenek Catarina. Lelaki itu tampak marah. Nenek Catarina seperti ingin menempel di lantai rumahnya. (Shirazy, 2015: 238).

Kutipan di atas menggambarkan sikap Baruch kepada Nenek Catarina yang tidak manusiawi, yakni menyeret Nenek Catarina untuk meninggalkan rumahnya. Tindakan tersebut mencerminkan energi psikis id karena dilakukan dengan tujuan 
memenuhi kesenangan dan kenikmatan pribadi. Baruch melakukan tindakan tanpa memerhatikan prinsip realitas dan nilai-nilai.

Kutipan di atas juga mengandung konflik internal tokoh Nenek Catarina, yakni pertentangan di dalam batin mengenai keinginannya untuk dapat tetap tinggal di rumahnya. Hal tersebut tercermin melalui sikap Nenek Catarina yang mengiba memohon belas kasihan dari anak tirinya, Baruch. Namun demikian, sikap Baruch tetap mempertahankan keinginannya untuk dapat mengusir Nenek Catarina karena rumahnya akan dijual.

Perubahan sikap terjadi tidak hanya pada tokoh Jason, tetapi juga pada tokoh Nenek Catarina. Berikut adalah data yang menggambarkan dorongan psikis yang melatarbelakangi sikap Nenek Catarina.

“... Aku pernah menganggapnya sebagai manusia rendahan, sebagai Amalek. Aku juga minta maaf kepadamu, Brenda. Aku pernah menganggapmu sebagai Amalek rendahan. Tapi Fahri sudah menjelaskan pandangan yang benar tentang Amalek." (Shirazy, 2015: 476)

Nenek Catarina mengalami penyesalan karena pernah memandang Fahri, Brenda, dan lainnya sebagai amalek, manusia rendahan. Sikap Nenek Catarina yang penuh penyesalan menunjukkan adanya tindakan yang dikendalikan oleh nilai baik dan buruk. Hal tersebut berkaitan dengan psikisme manusia berupa super ego yang bertugas mengawasi. Perubahan tersebut berkaitan dengan perbuatan-perbuatan Fahri yang selalu menolongnya. Tidak hanya Fahri, tetapi juga Brenda. Nenek Catarina tidak lagi memandang Fahri dan lainnya sebagai amalek. Dorongan psikis pada tokoh Nenek Catarina tercermin melalui tindakan dalam berpuasa. Hal demikian tergambar pada kutipan berikut.

"... Ini adalah hari ke-9 bulan Av, bulan kelima dalam hitungan kami. Kami wajib berpuasa."

"Karena memaksakan puasa itulah nenek sampai terkena dehidrasi berat." (Shirazy, 2015: 418)

Nukilan novel di atas mengandung deskripsi perilaku atau sikap Nenek Catarina yang ingin melaksanakan puasa, tata ibadah Yahudi. Hal demikian didorong oleh keyakinan atas ajaran agamanya untuk dapat berpuasa. Namun demikian, keinginannya tersebut tidak dapat dilaksanakan karena kondisi kesehatan Nenek Catarina yang terganggu, yakni mengalami dehidrasi berat. Kondisi tersebut membuat Nenek Catarina mengalami kesedihan.

Tokoh Baruch merupakan tokoh yang memiliki karakter yang bertentangan dengan nilai-nilai kebenaran. Tindakan yang dilakukan dipengaruhi oleh dorongan tertentu. Berikut adalah kutipannya.

“... Perempuan itu mengalami penderitaan luar biasa yakni diperkosa para durjana itu, pemimpin para penjahat itu bernama Baruch." Kata perempuan itu. (Shirazy, 2015: 685).

Penggalan tersebut memuat penggambaran tokoh Baruch yang bersikap tidak manusiawi, yakni melakukan tindakan pemerkosaan. Tindakan tersebut mengandung gambaran aspek id, yakni energi psikis dan naluri yang menekan manusia agar memenuhi kebutuhan dasar, seperti seks. Selain itu, penggalan tersebut memuat konflik batin yang dialami oleh Sabina dan Fahri. Hal tersebut terkait dengan perbuatan Baruch kepada tahanan penjara di Israel yang berjenis 
kelamin perempuan. Sikap Baruch yang dipenuhi energi psikis berupa id tergambar tidak hanya pada Sabina, tetapi juga pada ibu tirinya dan juga Fahri. Ia dipenuhi dengan keinginan yang tidak terkontrol oleh nilai-nilai kebenaran. Tindakan Baruch tergambar juga melalui data berikut ini.

"Kau benar, Benyamin. Ya, seperti itulah mereka keledai-keledai bodoh yag hanya menyesakki isi dunia saja. Hahaha...." Baruch terbahak-bahak. (Shirazy, 2015: 257-262)

Penggalan di atas memuat deskripsi masalah sosial yang dihadapi oleh Fahri dan Baruch. Selain itu, tergambar masalah kejiwaan yang dialami oleh tokoh Baruch dan Benyamin. Masalah tersebut tercermin dengan adanya energi psikis yang menekan Baruch dan teman-temannya untuk memenuhi keinginan dasar berupa menghina muslim. Tindakan tersebut mencerminkan struktur kepribadian berupa id karena tindakan Baruch dan teman-temannya adalah melecehkan Islam.

Konflik batin juga dialami oleh Fahri Abdullah yang mendengarkan percakapan Baruch dengan teman-temannya. Dapat dikatakan konflik batin karena adanya pergulatan dalam diri Fahri untuk membuktikan bahwa yang dikatakan oleh Baruch dan teman-temannya tidaklah benar. Sikap Fahri berbanding terbalik dengan sikap Baruch dan teman-temannya, Ia menawarkan Baruch dapat melakukan diskusi formal mengenai muslim. Tindakan tersebut mencerminkan sikap mempertimbangkan nilai baik dan buruk yang merupakan deskriptor dari aspek super ego.

Tindakan fisik yang dilakukan Baruch pada Sabina juga dilakukan ketika Sabina di dalam tahanan penjara Israel. Peristiwa tersebut tercermin pada data di bawah ini.

"Di sana aku disiksa sejadi-jadinya. Air keras dicipratkan ke mukaku yang berdarah. Punggungku dicambuk sampe hancur. Lalu Baruch menusuk kemaluanku dengan menggunakan tongkat besi. Ia tidak memperkosaku tapi hendak membunuhku dengan cara seperti itu...." (Shirazy, 2015: 686).

Penulis mendeskripsikan rasa sakit yang dialami Sabina, yakni penyiksaan dengan cara mencipratkan air keras ke muka, mencambuk punggung, dan menusuk kemaluan Sabina menggunakan tongkat besi. Penggambaran konflik eksternal tersebut memacu adanya konflik batin, yakni keinginan Sabina untuk keluar dan bebas dari tindak kejahatan Baruch sebagai tentara Israel. Adapun tindakan yang dilakukan oleh Sabina mencerminkan adanya pertimbangan nilai baik dan buruk, yakni ditunjukan dengan upaya menghindari niat jahat Baruch. Oleh karena itu, super ego tergambar dalam tingkah laku Sabina yang berdasar pada pemahamannya akan Alquran dan hadis.

Sementara itu, sikap Baruch mencerminkan aspek id. Ia bersikap dengan cara tidak manusiwai, mengabaikan nilai-nilai kebanaran. Id sebagai energi psikis dan naluri manusia agar dapat memenuhi kebutuhan dasarnya, seperti dalam hal ini adalah seks. Tindakan yang dilakukan oleh Baruch ini merupakan tindakan yang berdasar pada keinginan mencapai kesenangan.

Baruch adalah seorang Yahudi. Namun demikian, tidak semua Yahudi dideskripsikan bersikap seperti Baruch. Data berikut ini memuat gambaran sikap Madam Varenkan sebagai seorang Yahudi yang bersikap baik pada muslim.

"Ladies and Gentlemen, ketahuilah, saya Varenka. Saya seorang Yahudi. Tapi saya tidak setuju dengan apa yang dilakukan Zionis Israel di 
Palestina. Karena itu, saya bangga sekali bisa ikut andil dalam pertunjukan amal ini...." ujar Madam Varenka. (Shirazy, 2015: 300)

Pada penggalan tersebut terdapat gambaran ketidaksetujuan Madam Varenka atas tindakan yang dilakukan Zionis Israel terhadap Palestina. Deskripsi tindakan Madam Varenka tersebut menunjukkan adanya pertentangan antara keyakinan Madam Varenka yang seorang Yahudi dengan tindakan yang dilakukan oleh Zionis Israel. Madam Varenka memberikan pengakuan dan kontribusi dalam acara amal penggalangan dana untuk Palestina. Dalam hal ini, terlihat super ego yang menguasai tokoh Madam Varenka. Tokoh tersebut melakukan tindakan atas dasar nilai baik dan benar yang bersumber dari keyakinannya.

\section{Dorongan Piskis Tokoh Paman Hulusi}

Salah satu tokoh yang mengalami perubahan sikap dengan wasilah melihat kebaikan Fahri yang berusaha mengamalkan Alquran dan hadis adalah tokoh Paman Hulusi. Hal tersebut tercermin melalui nukilan beirkut ini.

“... Ia langsung ingat bahwa dirinya masih hidup memang karena diselamatkan oleh Allah, tetapi wasilahnya karena ditolong Fahri saat dikeroyok teman-temannya sendiri sesama bandit Kota Muenchen. (Shirazy, 2015: 133)

Penggalan novel di atas memuat penggambaran konflik batin yang dialami oleh tokoh Paman Hulusi. Pengarang menggambarkan permasalahan yang pernah dialami oleh tokoh Paman Hulusi di masa lalunya sebagai sebab perubahan sikapnya. Ia yang sangat membenci tokoh Keira dan Jason pun menyadari bahwa ia pernah mengalami masa-masa sulit menjadi bandit. Hal tersebut membuat tokoh Paman Hulusi memutuskan untuk menggunakan sisa usianya hanya untuk beribadah. Melalui penggambaran tersebut, diketahui adanya pendeskripsian aspek psikis berupa super ego, yakni adanya aspek hati nurani, nilai kebaikan, dan nilai kebenaran yang berdasar pada Alquran dan hadis. Tingkah laku yang tergambar pada tokoh Paman Hulusi dikendalikan oleh kejadian di masa lalunya yang menjadikannya bersungguh-sungguh untuk bertaubat.

\section{Dorongan Psikis Tokoh Hulya}

Setelah Fahri menikahi Hulya, terdapat konflik yang terjadi dalam pernikahannya. Berikut adalah data yang menunjukkan dorongan psikis tokoh Hulya dalam menyelesaikan permasalahannya.

"Ya Allah, jangan uji diriku dengan kegagalan membangun rumah tangga."

Doa Hulya berulang kali dalam sujud- sujudnya. Sudah tiga bulan ia bersabar. (Shirazy, 2015: 604).

Nukilan novel tersebut memuat konflik batin tokoh Hulya, istri Fahri Abdullah. Hulya mengalami masalah psikis karena permasalahan rumah tangganya dengan Fahri. Semenjak mereka menikah, Fahri tidak memberikan nafkah batin kepada Hulya karena ia selalu memikirkan istrinya Aisha yang hilang di tanah Palestina. Selain itu, tergambar struktur kejiwaan berupa super ego melalui kalimat, "Ya Allah, jangan uji diriku dengan kegagalan membangun rumah tangga." Dalam menghadapi masalah rumah tangganya, ia memilih berdoa kepada Allah Subhanahu wa ta'ala agar terhindar dari perceraian. Tergambar keyakinannya kepada Allah dan kesabarannya untuk mempertahankan rumah 
tangganya. Hal demikian juga dipengaruhi oleh dorongan rasa cintanya pada Fahri Abdullah.

\section{Dorongan Psikis Tokoh Ju Suh}

Tokoh Ju Suh bertanya pada Fahri mengenai muslim yang melakukan bom bunuh diri. Pertanyaan tersebut dikemukakan berdasarkan dampak dari pemberitaan mengenai tindak pengeboman yang diduga dilakukan oleh muslim.

"Jawaban secara antropologis, sosiologis, juga politis silakan dicari sendiri. Saya ada analogi sederhana. Jika kalian punya pohon apel atau mangga yang sedang berbuah, dan kau sudah merawatnya dengan baik, bisakah kalian pastikan seluruh buahnya baik? Tidak ada satu pun yang busuk? Tidak ada yang jatuh dari pohonnya sebelum matang?" Mahasiswi dari Cina spontan menjawab, "Tidak bisa. Selalu ada satu dua dari pohon itu yang buahnya tumbuh tidak seperti yang diharapkan. Satu dua tetap ada yang busuk. Tidak bisa semua buahnya sempurna. "Kalau kau punya pohon apel, hanya satu dua saja buahnya yang busuk, apakah fair mengatakan seluruh pohon apel itu busuk?" (Shirazy, 2015: 9).

Adapun tokoh Fahri Abdullah merespons pertanyaan tokoh Ju Suh dengan menganalogikan pohon apel. Tindakannya tersebut mencerminkan aspek psikis berupa super ego. Ia berupaya memberikan jawaban dengan menenujukkan sebuah kasus sederhana. Sikap Fahri tersebut menunjukkan pengamalan Alquran dan hadis karena ia tidak emosi dalam menanggapi pertanyaan yang juga berupa tuduhan.

"Kalimat pertanyaanmu itu tidak benar, dan bernada menghakimi. Itu tidak fair. Saya muslim dan saya sangat tidak suka dengan bom bunuh diri. Saya belajar teologi Islam di Universitas Al-Azhar. Hampir tujuh tahun saya di sana. Selama itu tidak sekali pun saya mendapatkan adanya ajaran bom bunuh diri. Saya mengambil master di Pakistan, juga tidak menemukan ajaran itu. (Shirazy, 2015: 8)

Cuplikan data di atas memuat gambaran struktur kepribadian tokoh Fahri yang dipengaruhi oleh Alquran dan hadis. Ia memberikan respons atas pertanyaan Ju Suh dengan menjelaskan bahwa ia tidak menemukan adanya ajaran bom bunuh diri dalam Islam. Dorongan psikis tergambar melalui proses belajar Fahri dalam memahami agamanya. Ia telah mempelajari teologi Islam di Universitas Al-Azhar dan di Pakistan. Data di atas menunjukkan sikap yang selaras dengan pengetahuannya tersebut.

"Lalu saya menyelesaikan Ph. D. di Freiburg, saya mengkaji manuskrip Arab Islam abad pertengahan. Sebuah manuskrip Tafsir Al-Qur'an karya Quthbuddin Asy Syirazy yang berjudul Fath al- Mannan. Dalam mengkaji manuskrip itu, saya harus menyelesaikan dan membaca tak kurang dari sepuluh kitab tafsir dari awal sampai akhir. Khatam dan tuntas. Dan saya tidak menemukan Al-Qur'an memuat ajaran bom bunuh diri. Silakan ditulis, justru Al-Qur'an melarang membunuh dan Al-Qur'an justru menyuruh menjaga kehidupan. Membunuh satu orang, sama saja membunuh seluruh umat manusia. Dan membiarkan hidup satu orang sama saja menghidupkan seluruh umat manusia. Ada di dalam Al-Qur'an, Surat Al Maidah ayat 32. Al-Qur'an juga melarang orang beriman berbuat kerusakan, dan melakukan perbuatan yang membahayakan diri sendiri." (Shirazy, 2015: 8) 
Kutipan tersebut memuat respons Fahri pada pertanyaan Ju Suh mengenai bom bunuh diri. Respons tersebut menggambarkan struktur kepribadian berupa super ego. Fahri menunjukkan tingkah laku yang berupaya mengamalkan Alquran dan hadis. Selain itu, terdapat penggambaran konflik batin karena sering ditemukan orang-orang yang mengaitkan Islam dengan peristiwa pengeboman. Hal tersebut disebabkan oleh pemberitaan di media massa yang menyebutkan muslim sebagai tokoh yang melakukan pengeboman.

Konflik yang berhubungan dengan keyakinan juga ditunjukkan pada data di bawah ini.

"Sebelum masuk ke data-data sejarah, cobalah Anda bayangkan, Kota London yang metropolis itu. Dengan sistem transportasi yang sangat teratur, kereta bawah tanah yang juga sangat teratur.... Coba bayangkan kalau London tanpa aturan dan tidak ada polisi lalu lintas yang mengatur, apa yang akan terjadi? Chaos! Kesemrawutan yang luar biasa! Kemacetan yang mungkin tidak akan bisa terurai sebab tidak ada yang mengurai! Juga bahkan terjadi serentetan kecelakaan yang tak terelakkan!” (Shirazy, 2015: 579).

Penggalan tersebut mengandung konflik yang diketahui melalui deskripsi tokoh utama mengenai kehidupan tanpa agama yang dianalogikan lalu lintas tanpa peraturan lalu lintas. Konflik tersebut bersumber dari pernyataan lawan debat Fahri mengenai kehidupan manusia tanpa adanya agama. Fahri menunjukkan sikap tenang yang mencerminkan keilmuannya dan keyakinannya akan kehidupan yang memerlukan aturan agama.

Sikap Fahri dalam penggalan di atas menunjukkan adanya cerminan kejiwaan manusia berupa super ego. Hal tersebut karena dalam situasi penuh pertentangan, Fahri tetap memilih jalan untuk bersikap tenang, teratur, dan menguraikan pandangannya yang berdasar pada keyakinannya. Struktur kejiwaan tersebut tergambar melalui tindakan yang dipilih oleh tokoh Fahri Abdullah. Sikap demikian didorong oleh pengetahuan dan keyakinannya pada ajaran agamanya.

\section{Dorongan Psikis Tokoh Profesor Charlotte}

Salah satu tokoh nonmuslim yang dekat dengan Fahri adalah Profesor Charlotte. Gambaran dorongan psikis tokoh Profesor Charlotte tergambar dalam cuplikan data berikut ini.

Orang seperti Anda menjadi tidak tertarik memeluk Islam bukan karena ajaran Islamnya yang tidak menarik, tapi karena perilaku kami yang tidak menarik. Maafkan kami, Prof, kami telah secara tidak sengaja menjadi penghalang cahaya indah itu." (Shirazy, 2015: 390)

Profesor Charlotte memandang Islam adalah agama yang paling sempurna. Tetapi, ia tidak memeluk Islam karena melihat peradaban muslim zaman sekarang yang jauh dari konsep Islam. Dalam hal ini tergambar adanya dorongan yang disebabkan tidak diamalkannya aturan dan konsep Islam oleh pemeluknya. Pengarang menggambarkan adanya konflik demikian juga pada tokoh Nenek Catarina. Nenek Catarina pun telah menerima kebenaran, tetapi ia tidak dapat menjadi seorang pemeluk agama Islam. 


\section{SIMPULAN}

Dorongan psikis menggerakkan atau melatarbelakangi perilaku setiap tokoh. Dorongan yang berasal dari aspek spiritualitas tergambar melalui tokoh Fahri, Sabina atau Aisha, Hulya, Paman Hulusi, Jason, Nenek Catarina, Madam Varenka, dan Profesor Charlotte. Dorongan memenuhi keinginan tanpa memperhatikan nilai-nilai tergambar melalui tokoh Baruch dan Keira. Adapun dorongan yang dipengaruhi oleh pemberitaan di media massa tergambar melalui tokoh Keira, Ju Suh, dan Jason. Namun demikian, terdapat perubahan sikap tokoh Nenek Catarina, Keira, Ju Suh, dan Jason yang dipengaruhi oleh adanya pengamalan Alquran dan hadis oleh tokoh Fahri Abdullah dan tokoh muslim lainnya, seperti Aisha/Sabina. Proses belajar dan pengalaman tokoh memberikan sumbangsih hadirnya dorongan, baik positif maupun negatif.

\section{DAFTAR PUSTAKA}

Aras, G. (2014). Personality and Individual Differences: Literature in PsychologyPsychology in Literature. Procedia-Social and Behavioral Sciences, 185(2015), 250-257.

Atin, M. M. (2018). Nilai-Nilai Aqidah dalam Novel Ayat-Ayat Cinta 2 Karya Habiburrahman El Shirazy. Insania, 23(2), 242-255.

Bahador, R. \& Zohdi, E. (2015). Alice Munro's 'Runway' in the Mirror of Sigmund Freud. International Journal of Applied Linguistics and English Literature, 4(2), 169-176.

Borchardt, D. H. (1984). How to find out in psychology. Pergamon Press.

Emzir \& Syaiful. (2016). Teori dan Pengajaran Sastra. Jakarta: Raja Grafindo.

Esten, M. (2013). Kesusastraan Pengantar Teori dan Sejarah. Bandung: Penerbit Angkasa.

Gammelgaard, J. (2011). Love, Drive, and Desire in The Works of Freud, Lacan and Proust. The International Journal of Psychoanalysis, 92, 963-983.

Hun, K. H. \& Ummi. (2018). A Comparison of The Concept of Romantic Love in The Novels Ayat-Atar Cinta 2 and Salju Sakinah. Malay Literature, 31(1), 98-123.

Imron. (2015). Dorongan Fisiologis, Psikis, dan Spiritual dalam Alquran. Tarbiyatuna, 6(1), 22-29.

Long, W. J. (2004). English Literature. PG Distributed Proofreaders.

Lodge, D. (2002). Consciousness and The Novel: Connected Essays. Secker \& Warburg.

McMahan. (2017). Literature and The Writing Process. Pearson.

Milles, Matthew B., \& Hubberan, M. A. (2014). Qualitative Data Analysis A Method Sourcebook Third Edition. Sage Publication.

Milner, M. (1980). Freud et I'interpretation de la literature. C. D. U. et Sedes Reunis.

Minderop \& Stanton. (2011). Psikologi Sastra: Karya Sastra, Metode, Teori, dan Contoh Kasus. Yayasan Obor Indonesia.

Mukti, W. I., Andayani, A., \& Wardani, N. E. (2017). Social Issues of Ayat-Ayat Cinta 2 Novel by Karya Habiburrahman El Shirazy. Komposisi, XVIII(2), 197-215.DOI: https://doi.org/10.24036/komposisi.v18i2.8431.

Mulyaningsih, I. (2015). Kajian Feminis Pada Novel "Ronggeng Dukuh Paruk" Dan" Perempuan Berkalung Surban". Indonesian Language Education And Literature (ILEAL), 1(1), 107-119. DOI: 10.24235/ileal.v1i1.75. 
Pangestu, N. A. \& Sunardi, F. X. D. (2016). An Incomplete Psychological Novel: a Psychoanalytical Analysis of Hazel Lancaster in John Green's The Fault in Our Stars. Journal of Language and Literature, 16(1), 20-28.

Prawira, P. A. (2012). Psikologi Pendidikan dalam Perspektif Baru. Ar-Ruzz Media.

Rani. (2014). The conflict of love and Islam: the main ingredients in the popular Islamic novels of Malaysia. South East Asia Research, 22(3), 417-433.

Rois, N. (2019). Konsep Motivasi, Perilaku, Dan Pengalaman Puncak Spiritual Manusia Dalam Psikologi Islam. Jurnal PROGRESS: Wahana Kreativitas dan Intelektualitas, 7(2), 184-198. https://doi.org/10.31942/pgrs.v7i2.3096

Rozak, A., Rasyad, S., \& Atikah, A. (2019). Fakta Kemanusiaan dalam Novel Ayat-Ayat Cinta 2 Karya Habiburrahman El Shirazy. Deiksis: Jurnal Pendidikan Bahasa dan Sastra Indonesia, 6(1), 9-29. https://doi.org/10.33603/deiksis.v6i1.1908

Schiffman, L. G., \& Kanuk, L. L. (2010). Consumer Behaviour (10th ed.). Prentice Hall.

Stanton. (2012). Teori Fiksi Robert Stanton. Yogyakarta: Pustaka Pelajar.

Sugiyono. (2016). Memahami Penelitian Kualitatif. Bandung: Alfabeta.

Yusuf, S. \& Nurihsan, A. J. (2011). Teori Kepribadian. Bandung: Rosdakarya.

Warsiman. (2016). Membumikan Pembelajaran Sastra yang Humanis. Malang: UB Press.

Wilcox, L. (1995). Sufism and Psychology. Abjad Book Designers \& Builders.

Wilcox, L. (2013). Psikologi Kepribadian. Yogyakarta: IRCiSoD. 